\title{
Godzenie celów społecznych z ekonomicznymi w przedsiębiorstwach społecznych: identyfikacja zbieżności i rozbieżności w ujęciu międzynarodowym
}

\author{
Agnieszka Żur
}

\begin{tabular}{|c|c|}
\hline & A B S T R A K T \\
\hline $\begin{array}{l}\text { Cel artykułu: Celer } \\
\text { czenie dla tego jak } \\
\text { integrują logikę sp }\end{array}$ & $\begin{array}{l}\text { n opracowania jest eksploracja czynników, które mają kluczowe zna- } \\
\text { przedsiębiorcy społeczni łączą cele społeczne z ekonomicznymi oraz } \\
\text { ołeczną z logiką działań prorynkowych w swojej działalności. }\end{array}$ \\
\hline $\begin{array}{l}\text { Metodyka badań: } \\
\text { nych z przedsiębio }\end{array}$ & $\begin{array}{l}\text { Badania opierają się na pogłębionych wywiadach fenomenologicz- } \\
\text { rcami społecznymi z Polski, USA i Wielkiej Brytanii. }\end{array}$ \\
\hline $\begin{array}{l}\text { Wyniki: Wszyscy } p \\
\text { społeczne, natomi } \\
\text { być silnie modero } \\
\text { wskazują na trzy rc }\end{array}$ & $\begin{array}{l}\text { rzedsiębiorcy wykazują się wysokim stopniem zaangażowania w cele } \\
\text { ast stopień zaangażowania w realizację celów rynkowych wydaje się } \\
\text { wany wcześniejszym doświadczeniem zawodowym. Wyniki badań } \\
\text { óżne podejścia w tym względzie - negacja, adaptacja i akceptacja. }\end{array}$ \\
\hline $\begin{array}{l}\text { Wkład i wartość } \mathbf{d} \\
\text { ganizacji hybrydov } \\
\text { aby zidentyfikowa } \\
\text { cji cele biznesowe }\end{array}$ & $\begin{array}{l}\text { odana: Wartością dodaną opracowania jest połączenie koncepcji or- } \\
\text { wych z dorobkiem badań nad przedsiębiorczością społeczną, po to, } \\
\text { ć główny czynnik różnicujący to, jak przedsiębiorcy społeczni realiza- } \\
\text { obok społecznych. }\end{array}$ \\
\hline Typ artykułu: & oryginalny artykuł badawczy \\
\hline Słowa kluczowe: & $\begin{array}{l}\text { przedsiębiorczość społeczna; przedsiębiorstwo społeczne; organiza- } \\
\text { cje hybrydowe; konkurujące logiki; konkurencyjne cele }\end{array}$ \\
\hline Kody JEL: & L26, M13, L31 \\
\hline Artykuł nade & Artykuł zaakceptowano: 22 marca 2019 \\
\hline
\end{tabular}

\section{Sugerowane cytowanie:}

Żur, A. (2019). Godzenie celów społecznych z ekonomicznymi w przedsiębiorstwach społecznych: identyfikacja zbieżności i rozbieżności w ujęciu międzynarodowym. International Entrepreneurship Review (previously published as International Entrepreneurship / Przedsiębiorczość Międzynarodowa), 5(1), 77-91. https://doi.org/10.15678/IER.2019.0501.05

\section{WPROWADZENIE}

Przedsiębiorstwa społeczne, jako podmioty, które wykorzystują narzędzia ekonomiczne do realizacji celów społecznych, nieprzerwanie do co najmniej dwudziestu lat pozostają przedmiotem zainteresowania naukowego jak również praktyki gospodarczej. Nadrzędną cecha przedsiębiorstw społecznych jest prymat celów społecznych nad komercyjnymi oraz spo- 
łecznej misji nad generowaniem zysku (Mair \& Martı, 2006; Vega \& Kidwell 2007). Kolejne cechy powtarzające się w literaturze tematu charakterystyczne dla przedsiębiorstw społecznych to budowanie społecznej wartości dodanej oraz odpowiedzialność wobec licznych i zróżnicowanych interesariuszy (Moss, Lumpkin \& Short, 2008). Przedsiębiorstwo społeczne zazwyczaj opiera się na sieci relacji i współpracy z licznymi i często bardzo różnymi podmiotami: beneficjenci społeczni, komercyjni klienci, właściciele, partnerzy społeczni, podmioty sektora publicznego, komercyjni dostawcy, pracownicy i wolontariusze. Interesariusze, z którymi przedsiębiorstwo społeczne utrzymuje bliskie relacje i buduje społeczną wartość dodaną najczęściej należą do różnych sektorów i pochodzą z "różnych światów" (Low, 2006; Spear, Cornforth \& Aiken, 2009). Te organizacje i instytucje, ich logiki, normy, standardy i wartości to jeden z najważniejszych czynników mających wpływ na funkcjonowanie przedsiębiorstw społecznych w przestrzeni publicznej (Starnawska, 2014).

Z uwagi na konieczność godzenia często rozbieżnych celów (społecznych i ekonomicznych) i oczekiwań swoich interesariuszy oraz równoległego realizowania działalności prospołecznej z komercyjną, przedsiębiorstwa społeczne określane są jako organizacje hybrydowe (Dohert, Haugh \& Lyon, 2014). Wyzwaniem charakterystycznym dla przedsiębiorstw społecznych jest skuteczne budowanie synergii pomiędzy społecznym a ekonomicznym wymiarem ich funkcjonowania w ramach sieci współpracy, w które są wplecione. Łączenie celów społecznych z ekonomicznymi sprowadza się w praktyce zarządzania do podejmowania decyzji przez przedsiębiorców społecznych. Dlatego też wcześniejsze opracowania sugerują, że to osoba, a nie organizacja jest właściwszych obiektem badań mających na celu poznać dynamikę godzenia rozbieżnych celów (Baron, 2006), gdyż to osoba przedsiębiorcy jest postacią centralną i decydującą w funkcjonowaniu przedsiębiorstw społecznych (Glińska-Neweś \& Karwacki, 2018).

Pomimo iż sporo wiemy na temat tego jak przedsiębiorcy społeczni łączą konkurujące cele swoich organizacji (Batko \& Bogacz-Wojtanowska, 2015; Pache \& Santos, 2013), to niewiele wiadomo co wpływa na różne strategie łączenia celów społecznych z ekonomicznymi. Poznanie co warunkuje budowanie skutecznych synergii pomiędzy konkurencyjnymi celami jest istotne, gdyż jest to centralne wyzwanie i czynnik warunkujący efektywność działania przedsiębiorstw społecznych (Besharov \& Smith, 2014; Pache \& Santos, 2013).

Niniejsze opracowanie ma na celu eksploracyjnie, poprzez badania jakościowe na ograniczonej próbie, zbadać determinanty sposobów jednoczesnego realizowania celów społecznych i ekonomicznych przez przedsiębiorców społecznych z trzech różnych krajów: Polski, Wielkiej Brytanii i USA. Przeprowadzone badania mają na celu identyfikację co różnicuje przedsiębiorców zakresie sposobów łączenia celów społecznych z ekonomicznymi i ich potencjalnych długoterminowych schematów działania. Na początku omówiono kluczowe zagadnienia teoretyczne dla podjętego tematu. Następnie przedstawiono metodykę badań i uzyskane wyniki. Opracowanie kończy się podsumowaniem i sugestiami przyszłych badań.

\section{PRZEGLĄD LITERATURY}

\section{Przedsiębiorstwa społeczne i ich założyciele}

Przedsiębiorstwa społeczne zostały przez wielu autorów zaliczone do skutecznych sposobów radzenia sobie ze społecznymi problemami i wyzwaniami współczesnego świata 
(Dees, 2007; Praszkier \& Nowak, 2011; Short, Moss, \& Lumpkin, 2009). Są to organizacje, których przedmiotem działania są innowacyjne przedsięwzięcia podejmowane na zasadach rynkowych w ramach lub na styku sektora prywatnego, publicznego i/lub sektora non profit w celu generowania korzyści społecznych (Wei-Skillern, Austin, Leonard, \& Stevenson, 2007). W takim rozumieniu, obszar działań przedsiębiorców społecznych rozciąga się od komercyjnych przedsięwzięć rynkowych poprzez nowatorskie koncepcje organizacji non profit po budowanie sieci współpracy pomiędzy podmiotami rożnych sektorów, o ile celem nadrzędnym i racją bytu jest wdrażanie innowacyjnego pomysłu do generowania korzyści w sferze społecznej. Taka definicja przedsiębiorstw społecznych zakłada niezależność samego przedsiębiorcy lub grupy przedsiębiorców i swobodę ich działania w ramach wolnego rynku. Jest zatem bardzo bliska istocie przedsiębiorczości.

Za przedsiębiorców społecznych literatura tematu uznaje osoby, które zakładają i prowadzą działalność gospodarczą aby osiągać cele społeczne (Vogel, 2005). To cele społeczne, społeczna misja i agenda działania leżą u podstawy intencji i celów przedsiębiorców społecznych. Dlatego określani są również jako agenci zmian społecznych i burzyciele dotychczasowej równowagi społecznej (Mair \& Marti, 2009) oraz jako kreatorzy społecznej wartości dodanej (Simms, 2009). Nawiązanie do koncepcji kreatywnej destrukcji Schumpetera nie jest bezzasadne. Przedsiębiorców społecznych łączy wiele wspólnego z tradycyjnymi przedsiębiorcami komercyjnymi.

Zasadnicza różnica pomiędzy przedsiębiorcą tradycyjnym (komercyjnym) a społecznym leży w podstawowym celu przedsięwzięcia/organizacji i rodzaju wartości jaką przedsiębiorca generuje. Tradycyjny przedsiębiorca, w wyniku identyfikacji i eksploatacji szans rynkowych, realizuje cele ekonomiczne i generuje wartość ekonomiczną, natomiast przedsiębiorca społeczny realizuje cele społeczne i generuje wartość społeczną. Nie oznacza to, że te dwa rodzaje przedsiębiorczości są rozbieżne. Obydwaj przedsiębiorcy charakteryzują się chęcią zmiany zastanej rzeczywistości, proaktywnością, gotowością do podjęcia skalkulowanego ryzyka i posiadają innowacyjne rozwiązanie, które burzy dotychczasową równowagę (Dees, 2007). Posiadają zatem wiele cech wspólnych. Różnica polega na priorytetach. Jak wspomniano powyżej, przedsiębiorca społeczny przedkłada cel społeczny nad ekonomiczny. Jednak niewykluczone jest, że będzie generował zysk, który zasili jego działalność społeczną. Natomiast przedsiębiorca tradycyjny dąży do wypracowania możliwie najwyższych korzyści finansowych, jednak często jest przyczynkiem pozytywnych zmian w sferze społecznej (np. poprzez generowanie miejsc pracy), które są efektem ubocznym jego działalności.

Przedsiębiorca społeczny, tak jak tradycyjny, opiera swoją działalność na ekonomicznym rachunku i efektywnym działaniu. Jak każdy przedsiębiorca, przedsiębiorca społeczny działa na własne ryzyko i odpowiedzialność, w ramach zasad rynkowych i każde jego przedsięwzięcia podlega naturalnej weryfikacji rynkowej. Skuteczne rozwiązania przetrwają, nieskuteczne upadną.

Autonomia przedsiębiorców i działanie w ramach wolego rynku to kluczowe cechy dla każdego rodzaju przedsiębiorczości, również tej społecznej. Oznacza to swobodę mobilizowania zasobów, zarówno finansowych jak i ludzkich oraz swobodne nimi gospodarowanie. Przedsiębiorcy społeczni, jak wszyscy przedsiębiorcy, powinni posiadać swobodę ko- 
rzystania różnych źródeł finansowania, działając niezależnie od struktur rządowych na własne ryzyko i odpowiedzialność posiadając możliwość szybkiego reagowania na zmiany, dostrajania się do potrzeb rynku i potrzeb społecznych.

Przedsiębiorczość społeczna jest obiecującym kierunkiem rozwoju, gdyż traktuje problemy i wyzwania społeczne z taką samą determinacją, kreatywnością i zapałem jak tradycyjna przedsiębiorczość.

\section{Przedsiębiorstwo społeczne jako organizacja hybrydowa}

Literatura tematu wyróżnia kilka bardzo charakterystycznych cech przedsiębiorstw społecznych, które wyróżniają te organizacje wśród innych. Pierwsza i najważniejsza wynika z faktu, że powołane zostają do życia w celu kreowania społecznej wartości dodanej przy wykorzystaniu instrumentów ekonomicznych i rynkowych. Oznacza to, że podlegają prawom rynku, jednak ich cele i misja ulokowane są poza rynkiem. Bardzo często przedsiębiorstwa społeczne są odpowiedzią na bardzo konkretny problem społeczny; punktem wyjścia jest sytuacja społeczna określonej grupy, która dzięki przedsiębiorczej wyobraźni, myśleniu i działaniu zostaje zmieniona poprzez wykorzystanie mechanizmów rynkowych (Żur, 2015). Ta dychotomia, rozpięcie pomiędzy światem wartości prospołecznych, altruistycznych i humanitarnych oraz światem zysku, rywalizacji i transakcji znajduje odbicie $\mathrm{w}$ wielu aspektach funkcjonowania przedsiębiorstw społecznych. Po pierwsze w formach prowadzenia działalności: przedsiębiorstwa społeczne funkcjonują w rozmaitych formach prawnych, od działalności gospodarczej osób prywatnych, poprzez partnerstwo publicznoprywatne po spółdzielnie, fundacje lub stowarzyszenia. Z uwagi na to, że w wielu krajach nie ma dedykowanej formy prawnej dla przedsiębiorstw społecznych, funkcjonują one czasami w dwóch lub trzech formach jednocześnie (Battilana \& Lee, 2014).

Po drugie wspomniana dychotomia znajduje odbicie w zróżnicowanych sieciach powiązań i relacji z podmiotami różnych sektorów. Z uwagi na koncentrację aktywności na sferze społecznej, przedsiębiorstwa społeczne są szczególnie wysoko kontekstualne, wplecione w sieć powiązań z otoczeniem i głęboko uzależnione od rozmaitych interesariuszy (Yunus, 2011). Dla przedsiębiorstw społecznych sieci partnerskich silnych relacji to jeden z kluczowych czynników rozwoju: to nie są organizacje które działają w pojedynkę, lecz są w przeważającej większości przypadków silnie zsieciowane (Starnawska, 2014). Każde przedsiębiorstwo społeczne posiada zarówno interesariuszy wewnętrznych jak i zewnętrznych, z których każdy zgłasza swoje oczekiwania. Według Short, Moss i Lumpkin (2009), jednym z najtrudniejszych aspektów zarządzania przedsiębiorstwem społecznym jest kształtowanie relacji z interesariuszami i nieustanne poszukiwanie dynamicznej równowagi pomiędzy interesami wszystkich interesariuszy. Do interesariuszy wewnętrznych, w zależności od formy prawnej, zalicza się pracowników, wolontariuszy, ewentualne rady nadzorcze lub doradcze oraz ewentualnych udziałowców. Dużo liczniejsza jest grupa interesariuszy zewnętrznych i obejmuje przede wszystkim klientów, beneficjentów, organy dofinansowujące działalność, instytucje finansowe, darczyńców, sponsorów, media, lokalną społeczność oraz wszystkie organizacje partnerskie. Każda z tych grup interesariuszy posiada swoją agendę i inaczej postrzega priorytety przedsiębiorstwa społecznego. W przypadku przedsiębiorstw społecznych czym innym jest efektywność w oczach odbiorców/beneficjentów, a czym innym w percepcji darczyńców, sponsorów, zleceniodawców czy też klientów komercyjnych. Wobec z każdej z tych grup przedsiębiorstwo społeczne ma „inną twarz" i postrzegane oraz oceniane jest z innej perspektywy. Dlatego też tak ważne jest 
aby przedsiębiorstwo jasno, konsekwentnie i spójnie komunikowało swoje cele i swoja misje społeczną (Praszkier \& Nowak, 2011). Wierność misji społecznej, skuteczna komunikacja zewnętrzna i konsekwencja w działaniu przyczyniają się do godzenia przeciwstawnych interesów różnych grup interesariuszy.

Kolejnym czynnikiem, który definiuje hybrydowość przedsiębiorstw społecznych, jest specyfika finansowa. Przedsiębiorstwa społeczne korzystają z różnicowanych form finansowania od kapitału filantropijnego, poprzez generowanie przychodu poprzez prowadzenie własnej działalności gospodarczej, aż do rządowych grantów, a ponadto ich najważniejsza grupa docelowa (beneficjenci) nie jest najczęściej źródłem ich przychodów. Kryteria stosowane przez organy wspierające i współfinansujące nie zawsze są identyczne. Organy administracji państwowej największą wagę przywiązują do wiarygodności przedsiębiorstwa społecznego, a zatem rekordu jego doświadczeń i dokonań, podczas gdy społeczne fundusze inwestycyjne (np. Acumen lub Ananda) szukają projektów innowacyjnych, przełomowych i trwale zmieniających istniejące rozwiązania systemowe w sferze społecznej. Sprostanie wymogom różnych instytucji wspierających rozwój jest zadaniem trudnym dla przedsiębiorstw społecznych.

W literaturze można rozpoznać trzy pryzmaty, przez które dualizm przedsiębiorstw społecznych bywa badany. Pierwszy związany jest teorią instytucji i bada hybrydowość organizacji w kontekście łączenia różnych logik instytucjonalnych; dotyczy ekonomicznej działalności organizacji trzeciego sektora, urynkowienia działalności organizacji sektora publicznego, czy też silnej agendy społecznej firm sektora prywatnego (Besharov \& Smith, 2014; Hensel, 2015). Drugi pryzmat dotyczy procesów; odnosi się do dominującej logiki organizacji i bada podłoża, przesłanki i schematy podejmowania kluczowych decyzji w przedsiębiorstwach społecznych (Spear, Huybrechts \& Nicholls, 2013). Trzeci pryzmat dotyczy jednostki i odwołuje się do rozbudowanego w latach osiemdziesiątych nurtu badań nad przedsiębiorczością dotyczącą cech przedsiębiorczych (traits theory) utrzymując, że to indywidualne cechy przedsiębiorcy mają decydujący wpływ na procesy decyzyjne (Liang, Peng, Yao, \& Liang, 2015).

Aby skutecznie realizować swoje cele, przedsiębiorstwa społeczne muszą poruszać się w różnych rzeczywistościach instytucjonalnych, w różnych logikach, różnych regułach gry i różnych światach wartości. Funkcjonowanie w różnych światach, może wywoływać napięcia i dylematy, którymi trzeba zarządzać. Badania Tracey i Phillips (2007) sugerują, że największym wyzwaniem dla przedsiębiorców społecznych jest godzenie i równoważenie logiki społecznej z komercyjną. Logika działań komercyjnych priorytetyzuje tworzenie wartości rynkowej i maksymalizację zysku, podczas gdy logika działań społecznych w centrum stawia budowanie społecznej wartości dodanej, kategorii odległej od rynkowej konkurencyjności. Te dwie przeciwstawne logiki instytucjonalne ciągną przedsiębiorstwo społeczne w dwóch przeciwnych kierunkach. Jednak obydwie logiki i obydwie perspektywy muszą być realizowane przez przedsiębiorstwa społeczne. Łączenie logik w kluczowych decyzjach oraz codziennej działalności wymaga świadomości różnic obydwu logik, rozumienia praw i zasad każdej z nich i wychwytywania punktów styczności (Pache \& Chowdhury, 2012). Logika rynku oznacza dostosowanie efektów działalności do praw rynku oraz komercjalizację czyli spowodowanie, że produkt lub usługa ma wartość rynkową i może być źródłem przychodu. Logika rynku wprowadza też ekonomizację procesów w przedsiębiorstwach społecznych, co jest cechą pożądaną w każdego rodzaju działalności. 
W przedsiębiorstwach społecznych konkurencyjne logiki instytucjonalne nabierają charakteru komplementarnego względem celów przedsiębiorstwa społecznego (Di Domenico, Haugh, \& Tracey, 2010). Przedsiębiorcy społeczni w niejednakowym stopniu integrują obydwie logiki; w zależności od zidentyfikowanych punktów styczności, budują synergię lub nie pomiędzy aktywnością prospołeczna a prorynkową (Pache \& Santos, 2013). Dotychczasowe badania nie określają jednoznacznie od czego zależy skuteczność integrowania konkurencyjnych logik ani czy jest to uzależnione od ekosystemu w jakim przedsiębiorstwa społeczne funkcjonują czy też od indywidualnych predyspozycji przedsiębiorcy. Dotychczasowe nieliczne i szczątkowe badania wskazują na istotność czynników indywidualnych. Autorzy podkreślają rolę orientacji przedsiębiorczej (Greblikaite, Sroka, \& Gerulaitiene, 2016; Żur \& Neumann, 2018) lub motywacji społecznej (Bartha, Gubik, \& Bereczk, 2018; Siebold, Günzel-Jensen, \& Müller, 2018). Wciąż istnieje wyraźna luka badawcza w zakresie naszego rozumienia co wpływa na zróżnicowanie strategii w tym zakresie.

\section{METODYKA BADAWCZA}

Celem niniejszych badań jest eksploracja czynników determinujących sposoby jednoczesnego realizowania celów społecznych oraz ekonomicznych oraz integrowania logiki społecznej z logiką działań prorynkowych przez przedsiębiorstwa społeczne. Badanie oparte jest na podejściu jakościowym, jak to ma miejsce przy zjawiskach kompleksowych i wielowymiarowych, kiedy nie znamy dokładnie zmiennych, nie potrafimy określić zależności, a mamy na celu raczej „wyprodukowanie i zinterpretowanie materialnych artefaktów które uczynią fragment badanego świata bardziej widocznym" (Denzin \& Lincoln, 2005, s. 3). Zastosowanie takiego podejścia w badaniach wynikało z przyjętego eksploracyjnego celu badawczego. Założono również że w celu optymalizacji i uwiarygodnienia pozyskanych danych należy posłużyć się metoda triangulacji metod badawczych. Dlatego tez w badaniu wykorzystano trzy komplementarne metody:

1. Pogłębione wywiady fenomenologiczne z przedsiębiorcami społecznymi, założycielami przedsiębiorstw społecznych.

2. Obserwacje w przedsiębiorstwie według przygotowanego arkusza obserwacji.

3. Analizę dokumentów zastanych pozyskanych w przedsiębiorstwie (sprawozdania z działalności, ulotki, broszury) oraz analizę informacji na stronie internetowej badanej organizacji.

Badanie przyjęło za metodę wiodącą wywiad fenomenologiczny z sześcioma przedsiębiorcami społecznymi z trzech różnych krajów (Polski, USA i Wielkiej Brytanii), jako że celem badania było uzyskanie perspektywy międzynarodowej, nie ograniczając się do kontekstu i ekosystemy tylko jednego kraju. Zjawiskiem (fenomenem) w centrum dociekań badaczki było łączenie logiki społecznej i rynkowej przez przedsiębiorców społecznych w prowadzeniu i rozwijaniu przedsiębiorstwa społecznego. Interpretatywne podejście fenomenologiczne (Interpretative Phenomenological Approach) ma na celu wygenerować bogaty, szczegółowy opis subiektywnego ludzkiego doświadczenia w zakresie badanego zjawiska (Smith \& Eatough, 2006).

Dobór respondentów był celowy i opierał się na następujących kryteriach: (i) co najmniej dwuletnie doświadczenie w prowadzeniu przedsiębiorstwa społecznego, (ii) co naj- 
mniej pięćdziesięcioprocentowy poziom generowania przychodu poprzez działalność rynkową oraz (iii) różne cele społeczne w obrębie próby badawczej. Dodatkowym kryterium była dostępność i otwartość respondentów. Respondenci zostali zidentyfikowani poprzez zawodową siec kontaktów (w czterech przypadkach) oraz samodzielnego poszukiwania respondentów on-line (w dwóch przypadkach). Dobór krajów z jakich pochodzą respondenci zdeterminowany jest z obszarem działalności zawodowej badaczki. Tabela 1 przedstawia zarys docelowej grupy respondentów.

Tabela 1. Profile respondentów objętych badaniem

\begin{tabular}{|c|c|l|l|}
\hline Kod & Kraj & \multicolumn{1}{|c|}{ Wiodący cel społeczny } & \multicolumn{1}{|c|}{$\begin{array}{c}\text { Obszar działalności } \\
\text { rynkowej }\end{array}$} \\
\hline Robert & Polska & Poprawa sytuacji zaniedbanych społecznie dzieci & Marketing \\
\hline Bartek & Polska & $\begin{array}{l}\text { Likwidowanie fizycznych i cyfrowych barier dla } \\
\text { osób z niepełnosprawnościami }\end{array}$ & $\begin{array}{l}\text { Konsulting, doradztwo, } \\
\text { audyt }\end{array}$ \\
\hline Adam & USA & Poprawa sytuacji młodzieży z wyrokiem sądowym & Design i usługi drukarskie \\
\hline Hanna & USA & Poprawa sytuacji imigrantów & Doradztwo prawne \\
\hline David & UK & $\begin{array}{l}\text { Niwelowanie nierówności społecznych oraz po- } \\
\text { prawa świadomości i edukacji w zakresie nie- } \\
\text { równości społecznych }\end{array}$ & Agencja eventowa \\
\hline Martin & UK & $\begin{array}{l}\text { Dostarczanie najwyższej jakości usług edukacyj- } \\
\text { nych dla dzieci z autyzmem }\end{array}$ & Edukacja \\
\hline
\end{tabular}

Źródło: opracowanie własne.

Wywiad fenomenologiczny jest ustrukturyzowany w stopniu minimalnym; to raczej respondent prowadzi konwersacje w obranym przez siebie kierunku (Cope, 2005). Przygotowaniem do przeprowadzonych wywiadów była analiza literatury i istniejących wyników badań oraz lista zagadnień do poruszenia. Kwestionariusz badania składał się wyłącznie z pytań otwartych i pozostawiał wystarczająco dużo miejsca na elastyczność, swobodne wypowiedzi respondentów oraz watki poboczne, które w badaniu stosunkowo nowych zjawisk okazują się czasami bardzo odkrywcze (Smith \& Eatough, 2006). Każdy z wywiadów trwał pomiędzy 90 a 180 minut, prowadzony był na terenie badanego przedsiębiorstwa i był nagrywany za zgodą respondenta.

Pierwszym etapem obróbki danych była transkrypcja wywiadów z wykorzystaniem arkusza excel i pierwotne kodowanie. Kody pierwszego rzędu były wynikiem wcześniej przyjętych aspektów badawczych oraz dodatkowych aspektów badanego zjawiska zasygnalizowanych przez respondentów w toku wywiadu. Kodowanie drugiego rzędu polegało na usystematyzowaniu i syntezie kodów pierwszego rzędu w ramach badanych jednostek (klasteryzacja doświadczeń) poprzez horyzontalizację wątków (Moustakas, 1994). Drugim etapem procesu analizy danych była analiza porównawcza pomiędzy badanymi jednostkami, identyfikacja i konstruowanie kodów przekrojowych, co pozwoliło zidentyfikować podobieństwa i różnice oraz emergentne schematy działania w ramach badanego zjawiska. Ostatnim etapem procesu badawczego było zaangażowanie literatury tematu do objaśniania zidentyfikowanych wątków i ich interpretacji oraz do wnioskowania końcowego. 


\section{WYNIKI BADAŃ}

Przeprowadzane badania przedsiębiorstw społecznych wskazują, że podmioty te jednoznacznie uznają prymat celów społecznych nad rynkowymi i wiodącą role swojej misji społecznej. Wszyscy objęci badaniem przedsiębiorcy społeczni kierowani są celami społecznymi, jakie przyświecały im przy zakładaniu przedsiębiorstwa społecznego. Niemniej jednak, niektórzy przedsiębiorcy w stopniu wyższym niż inni, uznają konieczność działalności rynkowej i tym samym głębiej angażują się w prowadzenie działalności rynkowej swojego przedsiębiorstwa. Uzyskane wyniki badań sugerują, że przyjęte kryterium różnicujące czyli „sposoby jednoczesnego realizowania celów społecznych oraz ekonomicznych oraz integrowania logiki społecznej z logiką działań prorynkowych" było fałszywie określone. Pozyskane dane wskazują, że de facto przedsiębiorcy społeczni różnią się podejściem i stopniem zaangażowania $w$ działalność rynkową i realizację celów ekonomicznych. Podczas gdy wszyscy respondenci uznają, że osiąganie celów biznesowych jest im potrzebne, to praktyka ich działania wskazuje na trzy różne podejścia w tym obszarze. Wczesne badania Peredo i McLean (2006) wskazywały no to, że pomimo iż, zdecydowana większość przedsiębiorców społecznych uznaje konieczność realizowania celów ekonomicznych, to waga tych celów rozciąga na długiej ciągłej i przybiera różne wartości. W obrębie badanej grupy respondentów zidentyfikowano trzy charakterystyczne punkty na tej ciągłej, do których możliwe było przyporządkowanie postaw respondentów. Dlatego przedstawione poniżej wyniki badań szeregują respondentów na trzy grupy w zależności od sposobu rozumienia i realizowania celów ekonomicznych względem celów społecznych.

\section{Grupa pierwsza: negacja}

Trzech spośród sześciu respondentów przyznaje, że rozumie logikę społeczną o wiele lepiej niż logikę rynkową. Pomimo iż zdaja sobie sprawę z konieczności generowania przychodu i tym samym konieczność realizowania celów rynkowych, plasują cele rynkowe bardzo nisko w swojej hierarchii celów organizacyjnych i woleliby się nimi nie zajmować. „Moim kompasem $w$ działaniu jest zmiana na lepsze jaka możemy przynieść ludziom, to zawsze było i będzie na pierwszym miejscu” przyznaje David i dodaje „naszym celem jest pomaganie ludziom w potrzebie i uświadamianie innym jak mogą pomagać. Chce aby każdy dzień się do tego celu przyczyniał. Nasza działalność komercyjna to konieczność i najchętniej nie pobierałbym żadnej opłaty od naszych klientów za organizowane dla nich wydarzenia." Przedsiębiorcy przyporządkowani do tej grupy to społecznicy z krwi i kości, ludzie pracujący od początku wśród najmniej uprzywilejowanych członków społeczeństwa. Nie posiadają wcześniejszego doświadczenia w prowadzeniu działalności komercyjnej i postrzegają działalność komercyjną jako przykry obowiązek: „biznes to dla mnie i dla nas terra incognita; zawsze patrzyłem na biznes jak na coś gorszego, bezwzględnego" zauważa Bartek. Dwójka z respondentów tej grupy otoczona jest w codziennej pracy ludźmi podobnie myślącymi, o podobnym doświadczeniu zawodowym. Trzeci respondent, Adam, ma wykształcenie graficzne i tematy biznesowe są mu równie odległe. Jego postawa ukształtowana jest osobistym doświadczeniem: „moje cele zawodowe zostały ukształtowane poprzez doświadczenia wyniesione z mojej dzielnicy; widziałem jak moi koledzy się staczają, wchodzą w konflikt z prawem i nie w pewnym momencie nie mają już ścieżki powrotu do normalności. Mi udało się zdobyć dobre wykształcenie, więc chcę taką ścieżkę młodym 
zagubionym ludziom otworzyć.” Bartek przyznaje: „wierzymy, że niepełnosprawni mają już dość trudne życie poprzez swoją niepełnosprawność; nie powinno być tak że bariery architektoniczne dodatkowo utrudniają im życie." Ta grupa przedsiębiorców powodowana jest głównie empatią i chęcią niesienia pomocy. Nie identyfikują się z celami rynkowymi i klientami rynkowymi, ale za to silnie identyfikują się ze swoimi beneficjentami. Dla nich samofinansowanie i niezależność finansowa nie są priorytetem: „nie jesteśmy niezależni finansowo i pewnie nigdy nie będziemy, to nie jest najważniejsze" zauważa David. Ta grupa przedsiębiorców społecznych dostrzega konieczność zaangażowania na rzecz generowania przychodu, jednak nie posiada wystarczającej wiedzy i doświadczenia, aby skutecznie podjąć to wyzwanie. „zajmowanie się komercyjnymi działami, marketingiem i sprzedażą odciąga mnie od tego co powinienem robić" mówi David. Osiąganie celów społecznych i ekonomicznych przebiega w ich organizacjach dwutorowo, w pewnym sensie niezależnie od siebie i nie kreuje pozytywnej synergii, a raczej napięcia i frustracje.

\section{Grupa druga: adaptacja}

W badanej grupie respondentów jedna osoba reprezentuje otwartą postawę wobec celów rynkowych i przywiązuje dużą wagę do ich realizacji. Martin jest z wykształcenia psychologiem i pedagogiem, specjalizującym się w edukacji dzieci z autyzmem. Piętnaście lat temu, wraz z kilkoma znajomymi założył szkołę i ośrodek terapii dla dzieci z autyzmem. Uważał, że w jej regionie nie ma miejsca, gdzie dzieci te mogłyby rozwijać swój potencjał, gdzie stosuje się najnowsze terapie i wyniki badań, gdzie dzieci nie czują się gorsze. Motyw podjęcia działalności był stricte altruistyczny, podobnie jak u respondentów z pierwszej grupy. Jednak Martin od początku zakładał, że chce jak najszybciej osiągnąć niezależność finansową i móc nie polegać na programach i grantach rządowych. „Wiedziałem, że muszę nauczyć się języka i logiki biznesu." Autonomia działania i eksperymentowania były dla niego kluczowe. „Z perspektywy lat doceniam podejście biznesowe do prowadzenia działalności społecznej. Misja społeczna to nie wszystko, nie zapewni skuteczności w działaniu." Martin reprezentuje przedsiębiorców społecznych, którzy uczą się praw rynku i wykorzystują je do osiągania celów społecznych. Efektem ubocznym tego procesu jest profesjonalizacja usług społecznych i wprowadzenie rachunku ekonomicznego do prowadzonej działalności: „Idealizm nie wystarczy, a nawet może sprowadzić kłopoty finansowe. Potrzebna jest struktura i jasne zasady działania; profesjonalne, transparentne, etyczne i solidarne." Martin potrafił dostosować swój model działania do oczekiwań rynku i komercyjnych klientów. Wykorzystał narzędzia biznesowe, aby rozwinąć swoje przedsiębiorstwo społeczne i kreować jeszcze większą wartość dla docelowej grupy beneficjentów. „Jestem przekonany, że obydwie nogi [społeczna i rynkowa] muszą być mocne, aby moja szkoła, szkolenia i warsztaty przynosiły zmianę w życiu dzieci." Świadome i selektywne wykorzystywanie narzędzi biznesu zostało zidentyfikowane w literaturze jako selektywne dopasowywanie (selective coupling) i polega na poszukiwaniu optymalnego i zrównoważonego łączenia wybranych elementów logiki społecznej z rynkową (Pache \& Santos, 2013).

\section{Grupa trzecia: akceptacja}

Dwóch spośród sześciu przedsiębiorców społecznych objętych badaniem uznaje biznes jako optymalne i najlepsze narzędzie do wprowadzania zmian społecznych: „biznes to najuczciwsze narzędzie, nie ma niejasności, jest czysta umowa. Wytwarzam coś, za co 
ktoś inny chce zapłacić" przyznaje Robert. Obydwoje przedsiębiorców posiada wcześniejsze doświadczenie zawodowe niezwiązane bezpośrednio z działalnością społeczną. Robert był przedsiębiorcą, a Hanna prawnikiem. Można uznać, że oboje kontynuują swoje zawody, ale w zupełnie nowej odsłonie. Założone przez nich przedsiębiorstwa społeczne mają bardzo jasno sprecyzowany społeczny cel o docelową grupę beneficjentów. Hanna zauważa: „mój styl pracy i codzienne czynności niewiele się zmieniły. Dalej jestem prawnikiem i zarządzam zespołem ludzi. Tylko, że teraz robię to w konkretnym celu, w który głęboko wierzę i który sama sobie wyznaczyłam." Robert przyjmuje podobną narrację: „prowadząc wcześniejszą działalność gospodarczą w sektorze maszynowym, czułem, że to nie to, coś było nie tak. Teraz robię cos co ma głęboki sens, a wcześniejsze doświadczenia sprawiły, że robię to dobrze." Obydwoje przyznają, że nie czują, iż porzucili biznes, nadal pracują w biznesie i doświadczają satysfakcji z sukcesów biznesowych swoich firm: „im więcej sukcesów biznesowych, tym więcej pozytywnego wpływu społecznego jesteśmy w stanie wygenerować dzięki osiąganym przychodom." Należy zaznaczyć, że przedsiębiorcy trzeciej grupy nie przedkładają celów rynkowych nad społeczne, natomiast sukces finansowy jest dla nich sytuacją pożądaną i wręcz naturalną i niezbędna do realizacji długoterminowej strategii społecznej (Batko \& BogaczWojtanowska, 2015; Pache \& Santos, 2013).

Poniżej przedstawiono graficzną reprezentację wyników badań (Rysunek 1). Wśród przedsiębiorców objętych badaniem nie odnotowano istotnych różnic w wadze przypisywanej społecznym celom ich organizacji. Wszyscy respondenci w swojej działalności byli motywowani i napędzani przekonaniem o potrzebie pracy na rzecz zmiany społecznej. Jak powyżej opisano, różnili się podejściem do celów rynkowych.

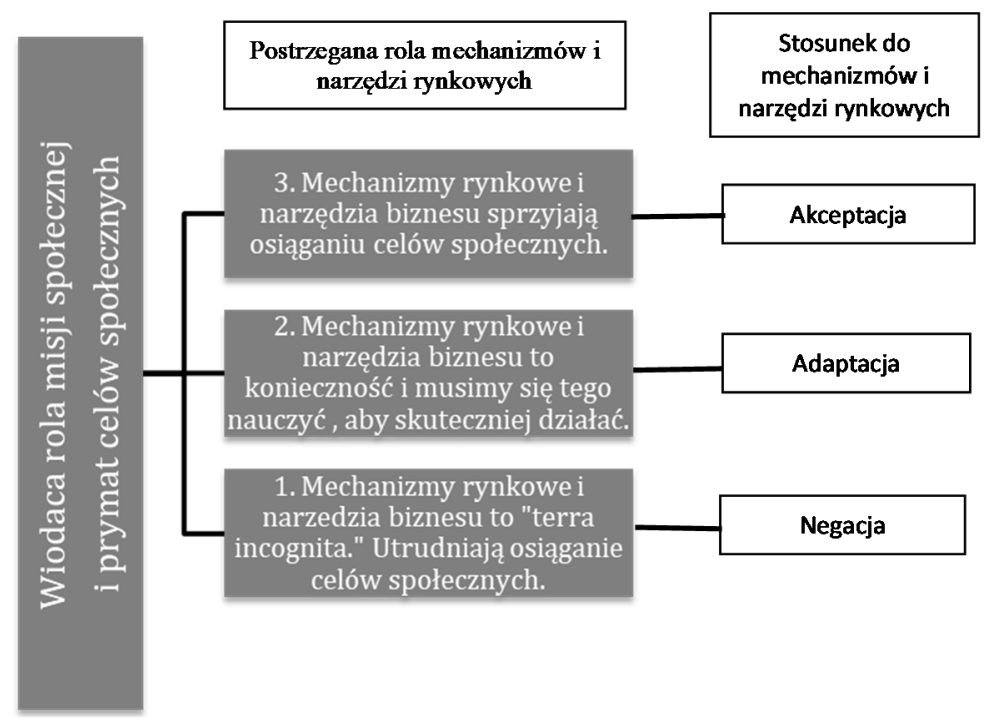

Rysunek 1. Trzy zidentyfikowane w badaniu postawy wobec celów ekonomicznych/rynkowych przez przedsiębiorców społecznych Źródło: opracowanie własne. 
Uzyskane wyniki badań nie wskazują jakoby narodowość lub kraj prowadzenia działalności był kryterium rozstrzygającym lub nawet istotnie wpływającym na wagę przykładaną do celów ekonomicznych. Pogłębione wywiady ujawniły, że kategorią różnicującą przedsiębiorców w obrębie trzech grup jest wcześniejsze doświadczenie zawodowe. Przedsiębiorcy z wcześniejszym doświadczeniem wyłącznie w sektorze społecznym, nie odnajdują się łatwo w rzeczywistości biznesowej, nie posiadają kompetencji zarządczych ani wiedzy umożliwiającej swobodne poruszanie się w ramach prawach rynku. Natomiast przedsiębiorcy o wcześniejszym doświadczeniu w biznesie posługują się swobodnie „językiem biznesu”, rozumieją prawa rynku i chętnie włączają się w grę rynkową. Zatem stopień zaangażowania w realizacje celów rynkowych wydaję się być moderowany wcześniejszym doświadczeniem zawodowym, posiadaną wiedzą i kompetencjami zarządczymi, które to czynniki determinują przeświadczenia, percepcje i styl działania przedsiębiorców społecznych.

\section{PODSUMOWANIE}

Celem przeprowadzonych badań była eksploracja czynników determinujących sposoby jednoczesnego realizowania celów społecznych oraz ekonomicznych oraz integrowania logiki społecznej z logiką działań prorynkowych przez przedsiębiorstwa społeczne. Jako że celem badań jakościowych nie jest poszukiwanie uogólnień, a jedynie opis poszczególnych przypadków i opisywanie zjawisk przez pryzmat subiektywnych ludzkich doświadczeń, to wnioski z badań należy traktować ostrożnie.

Badania wykazały jednoznaczną przewagę celów społecznych nad ekonomicznymi u wszystkich respondentów. Wszyscy respondenci charakteryzują się wysokim poziomem empatii, odpowiedzialności i chęcią niesienia pomocy. Przeprowadzone badania sugerują, że przedsiębiorcy społeczni różnią się nie tyle sposobami jednoczesnego realizowania celów społecznych oraz ekonomicznych, a raczej stopniem podejmowania celów ekonomicznych oraz stopniem zaangażowania w działalność rynkową. Tym co różnicuje ich strategie łączenia/balansowania celów społecznych z ekonomicznymi w badanej próbie jest stosunek przedsiębiorców do biznesu i jego narzędzi.

Wyniki badań wskazują na trzy różne podejścia w tym względzie - negacja, adaptacja i akceptacja. Możemy przypuszczać, że część przedsiębiorców społecznych, często nie posiadających żadnego wcześniejszego doświadczenia w działalności gospodarczej, najchętniej byłaby zwolniona z konieczności generowania przychodu i najpewniej się czuje w zaangażowaniu społecznym. Dwie pozostałe zidentyfikowane grupy w pełni uznają konieczność działań rynkowych, przy czym, jedni uczą się skutecznie działać na rynku (aby przetrwać), a inni, posiadający wcześniejsze doświadczenie w biznesie, inwestują swoje kompetencje w realizacje celów społecznych i są silnie zorientowani na sukces.

Kraj pochodzenia lub prowadzenia działalności nie wpływał na przynależność do żadnej z grup, co sugeruje, że zidentyfikowane prawidłowości są uniwersalne.

Pomimo iż przedstawione w opracowaniu wyniki badań posiadają walory poznawcze ograniczone do próby badawczej, to mogą stanowić punkt wyjścia do pogłębionych badań dotyczących czynników efektywności przedsiębiorstw społecznych. Należy bliżej przyjrzeć się potencjalnej korelacji pomiędzy stosunkiem do mechanizmów i narzędzi rynkowych przedsiębiorców społecznych, a wynikami ich działalności, i to zarówno w sferze społecznej 
jak i ekonomicznej (np. poziom samowystarczalności finansowej). Wyniki badań przedstawiają również ważne praktyczne implikacje dla programów edukacyjnych i szkoleniowych w obszarze przedsiębiorczości społecznej. Wskazują na koniczność podnoszenia nie tylko kompetencji biznesowych przedsiębiorców społecznych, ale przede wszystkim budowania pozytywnego obrazu biznesu jako przydatnego i skutecznego narzędzia generowania przychodów i budowania społecznej wartości dodanej.

Jak wspomniano, mała próba badawcza nie umożliwia generalizowania wyników badań, a raczej może być przyczynkiem formułowania hipotez badawczych do szerszych badań ilościowych dotyczących efektywności działania przedsiębiorstw społecznych. Ponadto warto, aby przyszłe projekty badawcze były poświęcone innym czynnikom (na poziomie indywidualnym, organizacyjnym, branżowym) wpływającym na to, jak przedsiębiorcy społeczni łączą cele społeczne z biznesowymi (kompetencje przedsiębiorcze przedsiębiorcy i pracowników, struktura zatrudnienia, kultura organizacyjna i inne).

\section{LITERATURA}

Baron, R.A. (2006). Opportunity Recognition as Pattern Recognition: How Entrepreneurs "Connect the Dots" to Identify New Business Opportunities. Academy of Management Perspectives, 20(1), 104-119. https://doi.org/10.5465/AMP.2006.19873412

Bartha, Z.S. Gubik, A., \& Bereczk, A. (2018). The Social Dimension of the Entrepreneurial Motivation in the Central and Eastern European Countries. Entrepreneurial Business and Economics Review, 7(1), 9-27.

Batko, R., \& Bogacz-Wojtanowska, E. (2015). Social Enterprise: Finding Identity Between Social and Economic Goals. Problemy Zqrzadzania - Management Issues, 13(4/56), 195-206. doi: 10.7172/1644-9584.56.12

Battilana, J.,\& Lee, M. (2014). Advancing Research on Hybrid Organizing, The Academy of Management Annals, 8(1), 397-441.

Besharov, M.L., \& Smith, W.K. (2014). Multiple institutional logics in organizations: Explaining their varied nature and implications. Academy of Management Review, 39(3), 364-381.

Cope, J. (2005). Researching Entrepreneurship through phenomenological inquiry: philosophical and methodological issues. International Small Business Journal, 23(2), 159-183.

Di Domenico, M., Haugh, H., \& Tracey, P. (2010). Social bricolage: Theorizing social value creation in social enterprises. Entrepreneurship theory and practice, 34(4), 681-703.

Dees, J.G. (2007). Taking social entrepreneurship seriously. Society, 44(3), 24-31.

Denzin, N.K., \& Lincoln, Y.S. (2005). The Sage Handbook of Qualitative Research. Thousand Oaks, CA: Sage.

Di Domenico, M., Haugh, H., \& Tracey, P. (2010). Social bricolage: Theorizing social value creation in social enterprises. Entrepreneurship theory and practice, 34(4), 681-703.

Dohert, B., Haugh, H. \& Lyon, F. (2014). Social Enterprises as Hybrid Organizations: A Review and Research Agenda. International Journal of Management Reviews, 16, 417-436. doi: 10.1111/ijmr.12028

Eatough, V. \& Smith, J.A. (2008). Interpretative Phenonological Analysis. In: C. Willig \& W.S. Rogers, (Eds.), The Sage Handbook of Qualitative Research in Psychology (pp. 165-194). London: Sage Publications.

Glińska-Neweś, A., \& Karwacki, A. (2018). Innovativeness of social economy entities in Poland. An empirical study from the perspective of Positive Organizational Scholarship. Nonprofit Management and Leadership, 28(3), 367-382. 
Greblikaite, J., Sroka, W., \& Gerulaitiene, N. (2016). Involving Young People in Polish and Lithuanian Social Enterprises by Fostering Entrepreneurial Skills and Abilities as Entrepreneurial Opportunity at University. Entrepreneurial Business and Economics Review, 4(3), 131-152.

Hensel, P. (2015). Wykorzystanie koncepcji konkurujących logik instytucjonalnych w badaniach organizacji. Organizacja i Kierowanie, 168, 47-60.

Liang, C.T., Peng, L.P., Yao, S.N., \& Liang, C. (2015). Developing a social enterprise performance scale and examining the relationship between entrepreneurs' personality traits and their perceived enterprise performance. Journal of Entrepreneurship, Management and Innovation, 11(3), 89-116.

Low, C. (2006). A framework for the governance of social enterprises. International Journal of Social Economics, 33(5/6), 376-385.

Mair, J., \& Marti, I. (2006). Social entrepreneurship research: A source of explanation, prediction, and delight. Journal of World Business, 41, 36-44.

Mair, J., \& Marti, I. (2009). Entrepreneurship in and around institutional voids: A case study from Bangladesh. Journal of Business Venturing, 24(5), 419-435.

Moss, T.W., Lumpkin, G.T., \& Short, J.C. (2008). The dependent variables of social entrepreneurship research. In: Frontiers of Entrepreneurship Research Conference (pp. 709-720). Babson Park, MA: Babson College.

Moustakas, C. (1994). Phenomenological research methods. London: Sage Publications.

Pache, A., \& Chowdhury, I. (2012). Social entrepreneurs as institutionally embedded entrepreneurs: Towards a new model of social entrepreneurship education. Academy of Management Learning \& Education, 11, 494-510.

Pache, A., \& Santos, F. (2013). Inside the hybrid organization: selective coupling as a response to competing institutional logics. Academy of Management Journal, 56(4), 972-1001.

Peredo, A.M., \& McLean, M. (2006). Social entrepreneurship: A critical review of the concept. Journal of World Business, 41(1), 56-65.

Praszkier, R., \& Nowak, A. (2011). Social entrepreneurship: Theory and practice. Cambridge: Cambridge University Press.

Short, J. C., Moss, T.W., \& Lumpkin, G.T. (2009). Research in social entrepreneurship: past contributions and future opportunities. Strategic Management Journal, 3, 161-194.

Siebold, N., Günzel-Jensen, F., \& Müller, S. (2018). Balancing dual missions for social venture growth: a comparative case study. Entrepreneurship \& Regional Development, 1-25. doi: 10.1080/08985626.2018.1554710

Simms, M. (2009). Insights from a management prophet: Mary Parker Follett on social entrepreneurship. Business and Society Review, 114(3), 349-363.

Smith, J.A. \& Eatough, V. (2006). Interpretative phenomenological analysis. London: Sage Publications.

Spear, R., Cornforth, C., \& Aiken, M. (2009). The governance challenges of social enterprises: Evidence from a UK empirical study. Annals of Public and Cooperative Economics, 80(2), 247-273.

Spear, R., Huybrechts, B., \& Nicholls, A. (2013). The role of legitimacy in social enterprise-corporate collaboration. Social Enterprise Journal, 9(2), 130-146.

Starnawska, M. (2014). Zachowanie poprzez sieciowanie w przedsiębiorczości społecznej w odpowiedzi na trudne otoczenie instytucjonalne - przypadek pięciu spółdzielni socjalnych. Problemy Zarzadzania- Management Issues, 4(49), 97-116. 
Tracey, P., \& Phillips, N. (2007). The distinctive challenge of educating social entrepreneurs: A postscript and rejoinder to the special issue on entrepreneurship education. Academy of Management Learning \& Education, 6(2), 264-271.

Vega, G., \& Kidwell, R. (2007). Toward a typology of new venture creators: Similarities and contrasts between business and social entrepreneurs. New England Journal of Entrepreneurship, 10(2), 15-28.

Vogel, D. (2005). The market for virtue: The potential and limits of corporate social responsibility. Washington, DC: Brookings Institution Press.

Wei-Skillern, J., Austin, J.E., Leonard, H., \& Stevenson, H. (2007). Entrepreneurship in the social sector (Vol. 13). London: Sage Publications.

Żur, A. (2015). Social Problems as Sources of Opportunity : Antecedents of Social Entrepreneurship Opportunities. Entrepreneurial Business and Economics Review, 3(4), 73-87. https://doi.org/10.15678/EBER.2015.030405

Żur, A., \& Neumann, Ch. (2018). Blending Conflicting Logics by Social Entrepreneurs - The Role of Entrepreneurial Mindset. Problemy Zarzqdzania-Management Issues, 16(1(73), 240-257.

The journal is co-financed in the years 2019-2020 by the Ministry of Science 


\section{Tytuł i abstrakt w języku angielskim}

\section{Social and economic goals of social enterprises: convergences and divergences in an international context}

Social enterprises have been repeatedly referred to as hybrid organizations, integrating markets and civil society and blending two different institutional logics, due to the fact that they pursue their social mission alongside business objectives. Hence one of the challenges inherent to social enterprises is constant balancing of often contradictory or competing social and economic objectives. The objective of this study is the exploration of factors that determine the ways that social entrepreneurs cope with the process of balancing competing goals. Based on data obtained through in-depth phenomenological interviews with social entrepreneurs from three countries, this study suggests that the prime differentiating factor of balancing social and business goals is the social entrepreneurs' attitude to business. It also identifies three ways of incorporating business goals into the management practice: negation, adaptation and acceptance. The value added of this research lies in merging research on hybrid organizations with social entrepreneurship research to deliver new insights to our understanding of social enterprises performance.

Keywords: Social enterprise; social entrepreneurship; hybrid organizations; competing JEL codes: L26, M13, L31

\section{Autor}

Agnieszka Żur pracuje jako adiunkt w Katedrze Przedsiębiorczości i Innowacji w Uniwersytecie Ekonomicznym w Krakowie. Jej zainteresowania naukowe obejmują przedsiębiorczość społeczną oraz tutoring akademicki.

Adres do korespondencji: Dr Agnieszka Żur, Uniwersytet Ekonomiczny w Krakowie, ul. Rakowicka 27, 31-510 Kraków, e-mail: zura@uek.krakow.pl ORCID (1) http://orcid.org/ 0000-0002-0535-0996

\section{Podziękowania i finansowanie}

Artykuł Powstał w ramach realizacji projektu nr 2018/02/X/HS4/00771 “Godzenie celów społecznych z ekonomicznymi w praktyce zarzadzania przedsiębiorstwami społecznymi w wybranych krajach Unii Europejskiej" finansowanego przez Narodowe Centrum Nauki.

\section{Prawa autorskie}

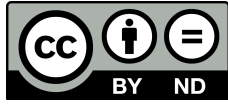

Ten artykuł został opublikowany na warunkach Creative Commons Uznanie autorstwa - Bez utworów zależnych (CC BY-ND 4.0 License) http://creativecommons.org/licenses/by-nd/4.0/ 
